Vol. 1, 2019

\title{
Press freedom and media ownership are factors that influence media performance: comparative analysis of these factors in USA and Nigeria
}

\author{
Modu Alh. Bukar \\ University of Maiduguri, Nigeria \\ modu140@gmail.com \\ Mohammed Kaka \\ A.D. Rufa'I College for Legal Islamic Studies Misau, Nigeria
}

Mai Dunoma Zannah

Atiku Abubakar College of Legal and Islamic Studies Nguru, Yobe State, Nigeria

\begin{abstract}
The paper is to examine the influence of press freedom and media ownership in the performance of the media institutions in the United States of America and Federal Republic of Nigeria. However, in order to set for such discourse there is indispensable need to review some of the normative theories of the media, which will enable us to locate the appropriate principles guiding the operation of the media in each countries under study. The subdivided into: Abstract, Introduction, Normative Theories of the press, press freedom in United States, press freedom in Nigeria (democracy and press freedom, freedom of information act and conclusion). The analysis concludes that, The United States even has provision in their law and constitution forbidding state interference in the area of information content and dissemination. In Nigeria however, the state control society including the mass media. In this regard, whether media are owned by public or private individuals, they are only meant to service the government in power and were forbidden to criticize the government or its functionaries. The paper recommends that, For Nigerian press to be free the country should militate the all laws or factors that against the press freedom and Members of the Nigerian press must adhere to the ethics of the profession, in order to compete with others freers press of the other countries.
\end{abstract}

Keywords. press, freedom, ownership, media, press freedom

\section{Introduction}

The press, radio, television and wire service and other modern media of mass communication do not operate in a vacuum, they operate within a well-organized social system governed by a wellestablished body of laws meant to guide the general conduct of the people in their day to day social intercourse.

However, the principles and ideologies along which societies are organized differ from one society to another and these principles have direct influence in the performance of the media in various countries. Some of these societies embraced capitalist philosophy whereas others favoured socialist or 
communist, authoritarian ideologies and this ideological difference greatly influenced the pattern of ownership of media institutions and defined the parameters of their operations in society.

In communists/socialists society for instance, the system of ownership is highly centeralised, all media institutions are owned and controlled by the state, in these societies there is direct control of media institutions therefore, the media serve as propaganda wing of the state. However, in capitalist society invariably, there is freedom of ownership of media institutions by individuals and corporate bodies and the media is presumably in word of Watson (2008) "servant to none but its readership in its task of informing, educating and entertaining".

While in the authoritarian ideology, government has the highest expression of institutionalized structure. The government control society which including mass media. In this regard, whether media are owned by public or private individuals, they are only meant to service the government in power and were forbidden to criticize the government or its functionaries.

The media in capitalist societies are seen as vanguards in the process of expanding the frontiers of freedom of individuals. They thrive on the general principles of freedom of expression and the press. But the questions that usually emanate from this general principle even from among communication scholars has always being "whose freedom the media are expressing, and how free is 'free' in situation dominated by competition, reliance on advertising and deeply affected by pattern of ownership...?" (McQuail, cited in Watson, 2008). This question forms the basis of this discourse.

The aims of the paper is to examine the influence of the press freedom and media ownership in the performance of the media institutions in the United States of America and the Federal Republic of Nigeria. However, in order to set the stage for such discourse there is an indispensable need to review some of the normative theories of the media as that will enable us locate appropriately the principles guiding the operation of the media in each of the countries under study.

\section{Normative media theories}

Normative theories according to Folarin (1998) are theories that help to explain the ways in which societal communication rules impinges on mass media structures, conventions and performance and highlight the consequences of non-convergence between societal communication principles and mass communication principles. Normative theories explain how media are constituted either as private or public enterprises; govern how they perform and what principles inspire practice (Watson, 2008).

Danis McQuail identifies six normative theories seeking to explain the role of media under varieties of social setups. These include: the authoritarian theory, the soviet communist theory, the free press or libertarian theory, social responsibility theory, development media theory as well as democratic participant theory. Each of these theories seek to explain how the media operate under a specific political system.

Authoritarian Theory: this theory described the situation where government in the hand of tyrant or a ruling elite exercising repressive power over the people, lay down the law as to what the media communicate. In this context, the media are nothing more than the servants of the state or the mouthpiece of the government. Kunczick quoted in Folarin (1998) locates the origin of the theory to state philosophy of "absolutism" in which recognition of the truth was entrusted to only a small number of sages able to exercise leadership in the kind to top down approach. In line with this, whether media are owned by public or private individuals, they are only meant to service the government in power and were forbidden to criticize the government or its functionaries.

Free Press or Libertarian Theory: this theory seek to explain the role of the media in promoting the principles of democracy. Its first principle is that, it is servant to none but its readership. Watson (2008) identified the press of the western world with free press philosophy. Free press theory thrives on the general principles of freedom of expression and of the press as enshrined in the first amendment of American constitution. On the basis of this free media claim fearlessness in the pursuit of truth, take provide in being the conscience and watchdog over the right of the people Watson (2008).

Social Responsibility Theory: here, the chief duty of the media operating within this theory is to raise conflict to the plane of discussion. In accordance with this theory, anyone who has ideas to express is free, but that should be done in recognition of the right of the individuals in the society. The theory 
balances the claim for freedom with responsibility Watson (2008). Under social responsibility theory, media operate to protect public interest; by this media have obligation that mount public stewardship.

Soviet Communist Theory: according to this theory, the main task of the press is to promote the socialist system and maintain sovereignty of the working class via the communist party (Folarin, 1998). The media in accordance with this theory were under direct control of the state. The role of the media in this context was to mobilise and sustain socialist revolution, to defend it from counter revolution and to protect it from the evil influence of capitalism. Censorship was acceptable if it meant that the people were shielded from ideas and information that might contradict or undermine the ruling ideology of the communist.

From these typologies of the normative theories, it is easier to locate where the media institutions in the United States of America and Federal Republic of Nigeria belong as regards to the philosophy guiding their practice. America being a democratic society rooted in capitalist economic system operate in line with the dictates of libertarian philosophy to promote the general principles of democracy and freedom of individuals in the society.

Under this form of arrangement the media enjoys a high degree sense of freedom to act as the public watchdog. This freedom is not restricted to the unrestrained right of the media to publish, but also include right to own, operate and control the media for imparting ideas and expressing opinion.

Comparatively however, the media institutions in Nigeria do not enjoy the same implemented freedom as their counterpart in the USA this is sequel to the system of the economic and implementation of laws and policies in each of the two countries. Though Nigeria granted freedom of expression, but there are some recognized restriction to the freedom been conferred to them.

\section{Press freedom in United States}

The United States has one of the world's strongest system of legal protection for freedom of the press, the first amendment Act of the U.S. constitution provides core guarantee of press freedom and the freedom of speech. While those rights have come under pressure at various time in the country's history, the independent court system has repeatedly issued ruling that protect and expand the right of the journalist to be free of the state control. Some 39 states have shield-laws that give journalists limited protection from revealing sources or other information in the course of their work. The federal government however, has no such protection, as an effort to adopt a shield-law has started in congress. The United States adopted the freedom of information act (FOIA) since 1966. While the administration of President George W. Bush had a somewhat restrictive attitude toward the release of classified document, the Obama administration announced a more expansive interpretation of the law in 2009, when Attorney General Eric Holder declared that record should be released to the public unless doing so would violet another law or cause unforeseeable harm to protected interests, including personal privacy and national security.

The press remains aggressive in covering scandal involving government figures, including highranking members of the Bush administration and its coverage of the Iraq war. At the same time, the United States continued to face a controversy over growing demands by prosecutors that journalists reveal confidential sources or provide access to research material in the course of criminal investigations.

Press freedom in the United States enjoys a strong foundation of legal protection in the federal constitution, in the state and federal laws, and in court decisions. The Supreme Court has repeatedly issued decisions that take an expansive view of freedom of expression and the press. In particular, court decisions have giving broad protection to the press from libel or defamation suits that involve commentary on public figures. An exception to judicial support for press freedom involves demands by prosecutors for information gathered by journalists in the course of their journalistic investigations, including material from confidential sources, in the most high profile case New York Times reporter Judith Miller was jailed for 85 days in 2005 for refusing to testify before a Federal Grand Jury in a case involving the leaking of the identity of a Central Intelligent Agency employee, Valerie Plame. As a result of the high profile nature of the Plame case and the actual imprisonment of Miller, many within the media are concerned that this has put a chill on investigative reporting by making potential 
sources more reluctant to come forward and confide in journalists who may no longer be able to ensure their anonymity.

Media coverage of political affairs is aggressive and often polarized. The press itself is frequently a source of controversy, conservatives and supporters of the Bush administration accusing the media of anti-administration bias, and the liberal accusing the press of timidity in covering the administration misdeeds. The appearance of enhanced polarization is driven to some degree by the growing influence of blog sites, many which are aggressively partisans. Nonetheless, most American newspapers make a serious effort to keep a wall of separation between news reporting, commentary and editorials. Ironically, the trend towards fewer family owned newspapers and more newspapers under corporate control has contributed to a less partisan, if blander editorial tone.

The media in the United States are overwhelmingly under private ownership. Nevertheless, National Public Radio, an entity partly funded by the government and partly funded by private contributions, enjoys a substantial audience. In the year 2005, the Chairman of the Corporation for Public Broadcasting (CPB) stepped down amid charges that he had attempted to politicize the agency.

The United States is a home of more than 1,500 daily newspapers geared primarily toward local readerships. However, the primary forms of news dissemination in the country through television news networks both cable and satellite, like CNN, Fox News and CBS.

\section{The press freedom in Nigeria}

Nigeria emerged from colonial system in 1960. In 1960 we have independent constitution which was indirectly rule by the Queen. In year the 1963 we have republic constitution. The provision of the laws were the same, except from the sections where they appeared differ them. While colonized, Nigerians suffered press freedom infractions from the colonial authorities. According to Momoh (2002, p.10) restrictive media laws could be said to have actually taken roots in 1903 with the enactment of Newspaper Ordinance of that year and the sedition Ordinance of 1909. As Momoh recalled, perhaps the most notorious press gag law was the 1917 Act. The author noted that "it brought together previous colonial laws".

No doubt, these laws were put in place to curb the perceived "excesses" of the local press and sufficiently frighten them to desist from attacking the Colonial Administration. Tellingly, most of those Draconian laws have remained in Nigeria's law books because the new rulers who took over from the colonialists were not interested in abrogating them. Not unexpectedly, therefore, in 1964, this earlier Act was amended and has been the basis of anti-press laws in Nigeria. The first civilian administration under Tafawa Balewa, the Prime Minister enacted the law. If the civilian administration was not particularly media-friendly, it was even worse with the subsequent military administrations, each of them trying to outdo each other in an effort to put the media in its "rightful place" (Nwanne, 2014).

There was the notorious Decree 4 of 1984, a rehash of an earlier piece of military law which sought to protect public officers against 'embarrassment' whether or not such publication was true or not. There was also the State Security Protection Decree 2 aimed at deterring the press from publishing certain information not approved by the military authorities.

Under Decree No. 4 of 1984 during the General Buhari regime, two journalists - Nduka Irabor and Tunde Thompson of The Guardian were arrested, tried and convicted. Their offence was that they published a speculator story on the possibility of the appointment of a certain Rtd General Hannaniya as Nigeria High Commissioner to United Kingdom. The military authorities were miffed at the 'leakage' of the information which was thought to be a well-guarded secret. At the trial, the journalists were asked to reveal the source of their information, a request that was turned down. They were subsequently sent to jail.

One of the Decrees that was enacted during General Ibrahim Badamasi Babangida's regime in 1987 was the Newswatch Proscription Decree which put the then frontline magazine in the coolers for six months. What was the magazine's offence? The authorities at time explained that the vibrant magazine published the unreleased report of the Political Bureau headed by Justice Cookey. The surprising 
aspect was that part of the report had previously been published in newspapers. Why the military took a harsh position against Newswatch remains a mystery even till this day.

In January 2018, RSF took part in an unprecedented press freedom mission to the US, resulting in a report published in May. The report shows that President's Trump's attacks on the media, via his Twitter account and in press conferences, are exacerbating an already hostile environment for journalists in the US.

The US and UK are respectively ranked 45th and 40th out of 180 countries in RSF's 2018 World Press Freedom Index. The US dropped two places after the first year of Trump's presidency.

\section{Democracy and press freedom in Nigeria}

The military rule in Nigeria had strongly attenuated press freedom. After decades of struggle against militarism by virtually all segments of the articulate publics, especially the press, the military reluctantly hand-over power to civilians on May 29, 1999. It was a momentous occasion as the mantle of leadership fell on Olusegun Obasanjo, a retired army general and former military head of state.

On ascension of office, Obasanjo managed, at times unsuccessfully, to control his bad temper. Even though he spoke of the need for a free press, his disposition and body language did not always support his public statements. Unlike when he was military head of state, he managed to conceal his famed contempt for the local press. Under his watch, security agents had invaded the African Independent Television (AIT), a credible private outfit (Nwanne, 2014).

After an eight-year tenure, Obasanjo handed over power in 2007 to Umaru Musa Yar'adua, a descendant from Katsina, North Central Nigeria. Mild-mannered, quiet but effective, Yar'Adua's relationship with the press was generally all right, except probably on one or two occasions when he lost control. On one instance, the highly credible Channels Television had aired a story about the failing health of the President and the intrigues associated with it. Yar'Adua did not find it funny as he reacted rather angrily. Yar'Adua, probably Nigeria's most honest president by admitting that the electoral process that brought him to power was flawed, eventually died in May 2010, just three years into his presidency.

The relationship between Nigerian press and President Goodluck Jonathan may be best described as that of cautious optimism. The president occasionally appreciates the role of an unfettered press in national development but often over-reacts to seeming bad press. One of such occasions occurred April 2013 when two reporters of the Leadership newspaper, Tony Amokeodo and Chibuzor Ukaibe were arrested, detained and later charged to court on charges of felony. In a swift reaction, just 72 hours after the journalists were arraigned in court, the Federal Government withdrew the charges against the reporters. According to Vanguard: sited in Nwanne (2014) "They had been accused of forging a document purported to have emanated from the Presidency".

One would have thought that the arraignment of Leadership reporters would be the end of such irritations until June 6, 2014 when a novel style of media harassment surfaced. Writing under the headline "Clampdown: NPAN Seeks end to Siege" one of Nigeria's tabloids, Sunday Sun wrote:

Following harassment of newspaper vendors/distributors and the seizure of large volumes of newspaper by soldiers who initially targeted Leadership. Daily Trust, The Nation and Punch, but later extended the siege to all major newspapers in the country for the second day yesterday (June 7, 2014), the Newspaper Proprietors Association of Nigeria (NPAN) held an emergency meeting in Abuja yesterday with representatives of vendors and slammed the government.

It described as unnecessary the growing attack on free speech by soldiers in Abuja, Kaduna, Kano, Jos, Maiduguri, Ibadan, among other cities, claiming to be acting on 'orders'. In a statement yesterday, its President, Mr. Nduka Obaigbena decried the assault on freedom of expression through the stoppage of distribution of newspapers as inconsistent with the values of any democratic society and the constitution of the Federal Republic of Nigeria. It therefore called upon the military authorities to lift the siege immediately and call the soldiers to order.

Despite the strongly worded statement released on June 7, 2014, as partly reproduced above, the authorities seemed to have remained adamant, prompting another statement from a larger organisation, 
the Nigeria Press Organisation (NPO). In a June 13, 2014 statement, the organisation cited military spokesman, Major-General Chris Olukolade as explaining that the clampdown "followed intelligence report indicating movement of material with grave security implications across the country using the channel of newsprint related consignments". Unimpressed by the explanation, NPO insisted that "This development is opening a new chapter in the potential dangers being posed to the citizenry and the media: a clear violation of the right of free expression and press freedom and the right of the public to know". The assault on press freedom this time is coming at a time the country is celebrating fifteen years of unbroken civil rule, a great achievement for a country that struggled against oppressive military rule for decades.

Another development which has the potential for further eroding press freedom in the recent directive to broadcast stations by the Nigerian Broadcasting Commission (NBC) the industry's regulatory body, that all live political broadcasts should be communicated to the commission at least 48 hours to airing time. This act of wanting to know what would go on air before broadcast time is a clear attempt at prior restraint because if the commission is not pleased with the material or personality involved it might possibly stop the programme. This amounts to giving too much power to itself, after all the commission has a code to guide radio and television stations on all aspects of broadcasting.

\section{Freedom of information act}

The Nigeria's former president Dr. Goodluck Ebele Jonathan, on Saturday 28 May, 2011 signed into law the Freedom of Information Act as passed by the National Assembly. That was one day after a copy of the bill was delivered to him by the Clark of the National Assembly, Salisu Mai Kasuwa.

The bill, which first made an appearance in the National Assembly in 1999, languished there in the years that followed as legislators squabbled over it and president Obasanjo expressed open hostility to it.

After Obasanjo departure, the bill was finally achieved some traction despite many other hurdles, and was finally passed by the National Assembly. Among other things, they claimed it would compromise National Security.

The new law is a testament to the staying power of civil society demonstrating how committed group can work together to ensure laws which support the right of the people. The special adviser to the president on media and publicity O. J. Abuah stated that, while objectives of the Act is to make public records and information more freely available, it is also to protect public records and information to the extent consistent with the public interest and protection of personal privacy.

He pointed out that, the new law would also protect the serving public officers from any adverse consequences of disclosing certain kind of official information without authorization.

Section (4) of the law provide that when a public institution receives an application for information, it shall make such information available to the applicant within seven days. If such institution feels that such information cannot be granted, it is to inform the applicant in a writing form and stating the reasons for such decision and the section of the law under which the refusal is made.

The relationship between the Nigerian press and the president Muhammadu Buhari is good, because since the beginning of the administration in 2015 no reporter of journalists been intimidated or arrest on his duty, except the recent attacked of Channels Television reporter Segun Salami was badly beaten by security agents in the central state of Kogi on 1 September. And members of the Directorate of State Services (DSS) beat Timothy Agbor of The Point Newspapers and Toba Adedeji of Osun Defender while they were covering a demonstration by civil servants in the southwestern city of Osogbo on 11 September (RSF, 2018).

RSF has tallied 53 cases of abuses against journalists since the start of the year, including 20 arrests and 23 cases of threats or physical violence.

Nigeria is ranked 122nd out of 180 countries in RSF's 2017 World Press Freedom Index after falling six places in a year.

The invasion of the Daily Trust by Nigerian Army on 6 January, 2019. According to Daily Trust armed soldiers have invaded Daily Trust head office in Abuja, hour after taking the regional office in 
Vol. 1, 2019

Maiduguri, Borno state and arrested the regional editor Uthman Abubakar and a reporter, Ibrahim Sawad.

One would have thought that, the arraignment of the regional editor and the reporter may be connected with the lead story of daily trust on Sunday Trust on 6 January, 2019 on military operation in the North East.

Against this background, Asemah (2011) outline some factors militating against press freedom in the country. Which includes:

Legal Pressure: even though press freedom is granted in the constitution, there is no statutory backup in Nigeria. Journalist do not enjoy press freedom as the constitution counteract each other for instance section 39 of the 1999 Nigerian constitution qualifies and tactically curtails freedom of expression and of the press. Subsection two of section 39 places prior restraint on the ownership of the media for the exercise of freedom of speech particularly on the broadcast media. Chigbo, (2007) observes that section 39 subsections 3 validates and justifies any law made for the purpose of preventing disclosure of information received in strict confidence while in the service of the state in government. Section 45 of the constitution further limits the exercise of freedom of expression and the press. "This shows that even though press freedom is guaranteed in the constitution of Nigeria, it is only a mere say as there are techniques used by government in Nigeria to dodge what has been guaranteed in the constitution". Economic And Political Pressure: The economic and political pressure in Nigeria makes some newspapers or radio station most especially government owned to publish things in support of the government by so doing the definition of press freedom is defeated.

Secrecy: Secrecy in Nigeria limits the right of the people to know, by hindering the press from having access to government sources and records. We have government agencies or officials evading journalist so that they cannot get information about government activities.

The following are the effects of ownership on the content of media as was stated in the work of Ekaterina Shmykova (2007): On individual level: content of media messages is affected by communicators' professional background, experience, attitude, values and belief and by communicators' professional background, roles, ethics and power within the organization. He added that organization must be routine work in order to control. These routine affect individual communicators' and their way of working.

On organizational level: content is affected by the economic goals of a media organization, its structure, internal policies, internal control, and organizational roles. Individual workers and their routines must be subordinated to the larger organization and its goals (shoemaker, 1991). The goals of any organization determined by the owners of that organization.

Ownership structure: Government-owned media outlets usually seen by social scientists as pursuing goal of social welfare and harmony, while privately owned media are seen as pursuing interests that are determined by desire to make profit.

\section{Conclusions}

The United States view that economic and social forces should be allowed to play prominent role and that freedom of free flow of information is necessary for the promotion of competition and democracy. The United States even has provision in their law and constitution forbidding state interference in the area of information content and dissemination. In Nigeria however, the state control society including the mass media. In this regard, whether media are owned by public or private individuals, they are only meant to service the government in power and were forbidden to criticize the government or its functionaries.

In the United States of America, there is a stable democracy, anchored on freedom of the individual and the press. The first amendment to the American Constitution states inter alia that "Congress shall make no laws abridging the freedom of the press". But in Nigeria, the writers of the constitution did not seem convinced that Nigerians deserved unconditional freedom, hence the frequent reasons to the word 'provided'. Such punctuation or vitiation of the freedom of the press in Nigeria often provides opportunity for those in authority to take advantage. 
Vol. 1, 2019

\section{Recommendations}

For Nigerian press to be free the country should militate the all laws or factors that against the press freedom.

Members of the Nigerian press must adhere to the ethics of the profession, in order to compete with others freers press of the other countries.

\section{References}

[1] Asemah (2011) Selected Mass Media Themes. Jos: Great Future Press.

Chigbo, R. (2007). Mass Media in Nigeria: Perspective on growth and Development. Makurdi:Aboki Publishers.

[2] Daily Trust, (2019). The Invasion of Daily Trust head Office by the Armed Soldiers. Retrieved on 17 January, 2019 from www.dailytrustonline.com

[3] Democracy, Political Right and Press Freedom Table. Retrieved June 22, 2018 from www.worldaudit.org/presstable.html

[4] Folarin, B. (2002). Theories of Mass Communication. Abeokuta: Link Publications.

[5] McQuail, D. (1983) Mass Communication Theory: An Introduction. London: SAGE

[6] Momoh, T. (2002). Nigerian Media Laws. Lagos: Efua Media Associates. Nwanne, B. U. (2008). Essentials of News Reporting and Writing. Lagos: Broada Publications.

[7] Nwanne, B. U. (2012). "The Mass Media and Development Communication: Emerging Issues in Nigeria" In O. D. Awaritefe and C. Ewhrudjakpor (Eds). Journal of Social and Management Sciences.7 (1).

[8] RSF (2018). The Incident between Soldier and RSF in Umuahia on 12 September, 2018. Retrieved on November 22, 2018 from www.rsfonline.com

[9] RSF (2018). 2017 World Press Freedom Index. Retrieved 25 November, 2018. www.worldaudit.org/presstable.html

[10] Shmykova, E. (2007) Effect of Mass Media Ownership on Serving Public Interest. Georgia: Georgia University Press.

[11] Shoemaker, P. J. (1991) Mediating the Message: Theories of Influence on Mass Media Content. White Plains, New York: Longman

[12] Vanguard (2014). "Nigerian Press Organisation (NPO). Crackdown on the Media: Our Stands". June 13, p.2.

[13] Watson, J. (2008) Media Communication: An Introduction to Theory and Process. New York: Palgrave Macmillan. 